International Research Journal of Management, IT \& Social Sciences
Available online at https://sloap.org/journals/index.php/irjmis/
Vol. 8 No. 6, November 2021, pages: 701-711
ISSN: 2395-7492
https://doi.org/10.21744/irjmis.v8n6.1970

\title{
Teaching-Learning Methods and Their Influence on the Development of Multiple Intelligences of Initial Education
}

\author{
José Bernardo Cobeña Álava ${ }^{\text {a }}$ \\ Liseth Estefania Aguirre Vera ${ }^{b}$ \\ Verónica Flores Tipán ${ }^{c}$ \\ Gissella Valentina Loor Pinargote ${ }^{\mathrm{d}}$
}

Article history:

Submitted: 27 September 2021

Revised: 18 October 2021

Accepted: 05 November 2021

\section{Keywords:}

diversity;

influence on learning;

multiple intelligences;

student population;

teaching-learning method;

\begin{abstract}
When you start in the teaching process in the initial stage, methods are applied to develop the intelligence of the students. At present there are still teachers who apply traditional methodologies and who continue with the scheme where the teacher is the protagonist of learning, without noticing that the educator creates his learning from his need and interest, the teacher should only be a moderator or guide, in this stage. An investigation was carried out to determine the influence of teaching-learning methods in the development of multiple intelligences in initial education. Surveys were applied to teachers, using deductive, bibliographic, descriptive, and historical methods. Several authors were studied, obtaining as a result that teachers must propose challenges and obstacles to students in different subjects, for the student to develop new ways of understanding and learning using the appropriate methodological strategies such as play corners; With this suggestion, it is sought that the teacher is also creative when teaching his class.
\end{abstract}

International research journal of management, IT and social sciences (C) 2021. This is an open access article under the CC BY-NC-ND license (https://creativecommons.org/licenses/by-nc-nd/4.0/).

\section{Corresponding author:}

José Cobeña Álava,

Pontificia Universidad Católica del Ecuador, Extensión Manabí, Portoviejo, Ecuador.

Email address: davis_jose25@hotmail.com

\footnotetext{
Pontificia Universidad Católica del Ecuador, Manabí, Portoviejo, Ecuador

Pontificia Universidad Católica del Ecuador, Manabí, Portoviejo

Pontificia Universidad Católica del Ecuador, Manabí, Portoviejo

${ }^{4}$ Pontificia Universidad Católica del Ecuador, Manabí, Portoviejo
} 


\section{Introduction}

The social changes and the technological advances within the society and the path for which the educational processes take place in the process of transformation and innocence of constant manner, this is the end of the development of different differences and a new form of application during the actual development. The child needs to discover their abilities and skills, which will help them to face the world that surrounds them, they must develop starting from their experiences, from their social and family context, which helps them to strengthen more creative thinking and above all to give answers to your unknowns that arise during your education process (Cunska \& Savicka, 2012; Bezanilla et al., 2019). Educational design in recent decades is applying innovative universal learning models, where children are considered potential entities capable of developing each of the intelligence, being they who build learning through curiosity, experimentation, discovery and taking advantage of their innate inclination towards the game, making their cognitive process more productive and with successful results.

Through recreation, children acquire abilities, skills, motor skills, communication, and the affective-social part that enables learning. (Barrantes Montes, 2017), states that play is not an exclusive activity for boys/girls since in all stages of the human being this develops playful activities with various objectives and with its specificities, which contributes to strengthening their integral development. Childhood is not a mere step into adulthood, but it has value in itself, it is the most important period of the human being, in which the bases of the personality will be formed. Children begin to establish social relationships and cognitive connections; this will allow them to create and recreate knowledge with the help of others and their environment. Through play, the child will discover and know the pleasure of doing things and being with others (Chamorro, 2017), it is a tool that generates motivation and dynamism, it is worth mentioning that it improves attention and memory.

Teaching-learning methods are considered as pedagogical tools for education, they allow the ability for children to act dynamically in the development of the class, they at the same time play a significant role during the assimilation of knowledge where the teacher organizes and directs the pedagogical process, this is one of the six components of the educational process. It is considered that in education varieties of methods are used, so the appropriate one must be chosen for the group of children with whom one is going to work, making a review of multiple intelligences, their biological aspects, and what are the factors that intervene. At present, achieving the integral development of children by stimulating each of their intelligence has become a necessity of the first order. To achieve this objective, teachinglearning methods that use activities where they develop as active individuals of their learning are being incorporated into the educational procedures of the initial level, through games, experimentation, simulation, and discovery.

Children understand and experience the world around them, through the experiences they acquire within the family and social environments. (Saquinga Alcaciega, 2016), states that: learning by discovery, the teacher organizes the class so that students learn through their participation. Usually, a distinction is made between discovery learning, where students do much of their work, and guided discovery, where the teacher provides direction. In most situations, it is preferable to use Guided Discovery. Intriguing questions, ambiguous situations, or interesting problems are presented to students. Instead of explaining how to solve the problem, the teacher provides the appropriate materials, encourages students to make observations, develop hypotheses and check the results, in this context the student shows interest in learning by helping them become autonomous and independent.

\section{Materials and Methods}

The methods that were used in the research were the deductive ones that allowed obtaining information based on the data and real theories of how the results influence the teaching-learning process in the development of multiple intelligences, in addition to interpreting the meaningful through logical reasoning of the phenomenon to later compare its validity within the research, in the same way, the bibliographic was used, allowing a reliable review of the literature in addition to collecting and organizing critically evaluating the information, the descriptive one for the analysis of the different situations and manifestations (Alcivar et al., 2020; Zambrano et al., 2021). The documentary research of different authors on the application of these was used; the history for the analysis of the evolution of the teachinglearning process in students. The survey technique was applied to teachers of the Diana Esther Guerrero Vargas Educational Unit of the San Jacinto Spa, Charapotó Parish, Bahía de Caráquez Canton, to recognize the educational reality in the teaching-learning process and how it influences the development of the multiple intelligences. 


\section{Results and Discussions}

For the development of research in the learning process, the types of multiple intelligences developed by Howard Gardner were taken into account, as shown in figure 1.

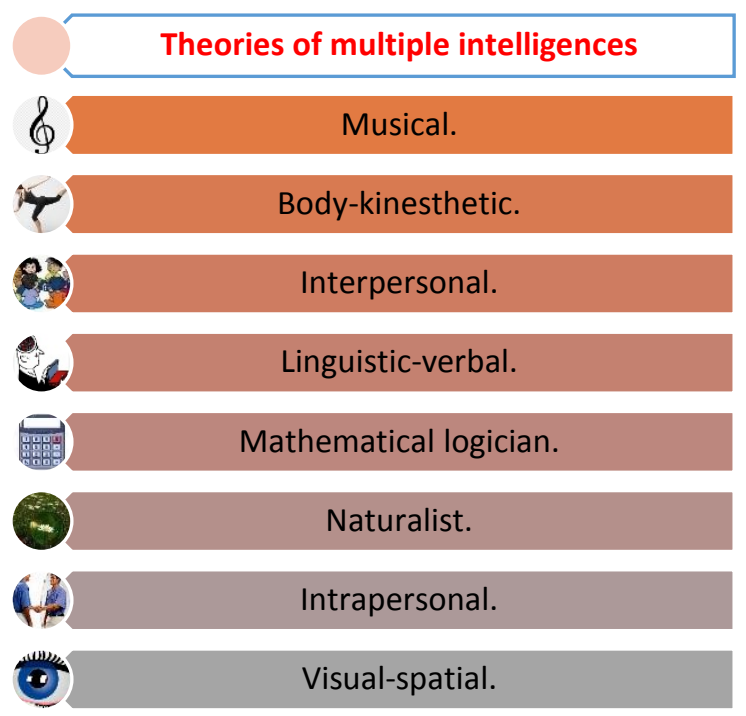

Figure 1. Multiple intelligence theory

Source: Own elaboration, contents taken from the UNIR (2019)

\section{Definition of intelligences}

The IQ of people varies throughout life, according to (Ardilla, 2011), which suggests that intelligence is a set of cognitive and behavioral skills that allows efficient adaptation to the physical and social environment. It includes the ability to solve problems, plan, think abstractly, understand complex ideas, learn from experience. It is not identified with specific knowledge or with specific abilities, but rather it is a general cognitive ability, of which specific abilities are part. The cognitive processes are focused on discovering the potentialities that each human being includes in their daily life, this determines that the child through their social and family environment acquires skills that strengthen their learning; In other words, the contextualization of the different scenarios that lives at home creates in the individual's behavior new scenarios of how to face life's challenges and give solutions to the problems presented; however, it should be guided by teaching at home and strengthening it at school, which allows an adequate integral formation of the person.

\section{Definition of multiple intelligences}

The theory of multiple intelligences according to (Torres-Silva \& Díaz-Ferrer, 2021), responds to the philosophy of person-centered training, under the premise that there is no single and uniform way of learning; on the contrary, given that people. Most of them have a wide spectrum of intelligence, so depending on the function, it can be learned based on the characteristics of each one. According to bibliographic research, 8 types of multiple integencies have been identified, which develop in the individual, to solve situations within the environment, based on these investigative and cited antecedents, the formation of the human being depends a lot on the social context and training from home, the discovery of multiple intelligences is present from the fact that as human beings we use the senses to recognize different present situations, exemplifying this conception, the child who begins from his childhood to create his learning scenarios is awakened a new scheme of seeing life and discovering their inclination to professionalize, in other words, if the child begins to assemble structures with objects from the environment, it reveals part of their intelligence and therefore responds to their needs.

Álava, J. B. C., Vera, L. E. A., Tipán, V. F., \& Pinargote, G. V. L. (2021). Teaching-learning methods and their influence on the development of multiple intelligences of initial education. International Research Journal of Management, IT and Social Sciences, 8(6), 701-711. https://doi.org/10.21744/irjmis.v8n6.1970 


\section{Musical intelligence}

This type of intelligence develops skills and dexterity in children when listening to the musical rhythm. (Figueroa et al., 2021), indicates that it is the ability to produce and appreciate the rhythm, tone, and timbre of sounds, and to value the different forms of musical expressiveness. It is often heard that when the child is in the mother's womb, he should learn to listen to music, this develops his hearing, however, on many occasions it is done to have relaxation or tranquility; Starting from this premise, the musical part in infants produces other intelligence attached to their abilities, that is, the child who listens carefully can interpret the content, can express in a bodily way what the music expresses and also issues judgment criteria from its abstraction. This intelligence is one of the most complete because it is complementing various skills that help the child discover a range of opportunities in his future life.

\section{Body-Kinesthetic intelligence}

In the field of development of multiple intelligences, this is part of daily (Ruiz, 2016), life, as well as manifests it, which is responsible for controlling body movements and the ability to manipulate objects, enables us to master our body, move, move, express ourselves physically and participate in games; Also in the musical is linked to the bodycinemas When a song is heard rhythmically, the child awakens the ability to give the body a movement according to what is expressed in the lyrics of the music, not only as part of dance or choreography but also in the game of their learning, which improves the state of health and emotional of the human being.

\section{Interpersonal intelligence}

The scenarios of each child show different styles of learning, how they live, their social behavior, how they understand their environment, to give them real answers to different situations, this attitudinal maturity marks a different scheme in the development of their skills, done new forms of learning appear, for this according to (Heredero \& Ceballos, 2017), manifests that this intelligence consists of the ability to understand the intentions, motivations, and desires of other people, achieving work and relationships effectively with others, also broad how to treat those who are involved, to perceive what other people do not see, in many cases the child reacts in a more assertive way than the adult.

\section{Linguistic or verbal intelligence}

The children who enter the initial levels are given as a task the interpretation through the linguistic part of the characters of a story or comic strip that interests them, from this premise they develop imaginative scenarios of how this story would be relating them to the experience itself, and interpreting new knowledge, before this, (Ruiz, 2016), states that linguistic or verbal intelligence is used to read, write, tell stories, memorize data or think with words. It is presented in the sensitivity to understand phonemes, verbal structures, meanings of words, and everything related to language, this intelligence is normal in writers, poets, lawyers, teachers, charismatic leaders, and other professions that use skills such as communicating, who have greater linguistic intelligence, usually possess greater capacities of transmission and acquisition of knowledge.

\section{Mathematical logical intelligence}

The ability to use numbers effectively, calculation, and proper reasoning in numerical situations was seen by (Figueroa et al., 2021). This intelligence allows to easily solve mathematical statements and propositions, functions, equations, derivatives, calculation problems, and inferences, as well as handling information and communication technologies (ICT) and their specific languages, computer programming (textual, iconic, visual, graphic, sound). By referring to this type of intelligence, the child is led to solve numerical situations, in this case, the initial education student still does not correctly identify the numbers but can do so in a reasoned and sequential way according to the strategy used by the student. teacher in the classroom, which can be games where you can think following rules of logic. With this intelligence the learner as he grows up can see things differently, he relates the language to define the things that happen in the world, beyond we can think coherently, detect regularities in the relationships between things, and reason logically (Zou et al., 2015; Sulaiman et al., 2010). 


\section{Naturalistic intelligence}

$\mathrm{t}$ is the ability that people have to distinguish, classify and use elements of the environment (objects, animals, or plants), in all rural or urban environments referred to by (Figueroa et al., 2021). This implies the understanding of the natural world, the scientific observation of nature, the study of its processes, the appreciation of life in all its splendor and manifestations. In this educational stage, the early childhood child still does not classify all objects correctly, for example, spatially if the child is ordered to identify which are the small and large objects, he can probably make them, but if you tell them that classify plants or animals, they will not do it according to the real thing, they use the individual logic of their environment, in which they can identify them by recognizing characteristics or differences between them, this intelligence adapts to children with higher levels of knowledge.

\section{Intrapersonal intelligence}

According to (Cabezas Gómez, 2017), it has to do with knowing yourself; recognizing and managing the world of emotions and feelings, and managing and guiding their behavior. In this intelligence, the ability that the infant discovers is emotional and feeling, attached to Gardner's theory for this age, he states that it is somewhat foggy and difficult to distinguish from other forms of intelligence, but it can be said that intelligence intrapersonal refers to the degree to which the internal aspects of the way of thinking, feeling and acting are known, it represents our ability to know each individual and the intervention on their psyche, in a broad sense.

\section{Inteligencia visual-espacial}

The ability to think in three dimensions according to (Figueroa et al., 2021), is the ability to perceive the visual and spatial world accurately and carry out transformations based on these perceptions. It can originate or decode graphic information from the perspective. From this background, this type of intelligence is present in all human activity when it comes to guiding, giving instructions to another person, driving, distributing furniture at home; The reality is that human intelligence is much more than the intellectual quotient of each one, considering that the child observes in a more detailed way the phenomenon or object of his interest, takes it to his experience and transforms it, creating an imaginary scheme, describing it according to its environment. To know the fulfillment of the multiple intelligences, the survey was applied to the teachers of the Diana Esther Guerrero Vargas Educational Unit of the San Jacinto Spa, in the city of Bahía de Caráquez, to learn about the teaching-learning methods that they apply in their classrooms class is shown in figure 2.

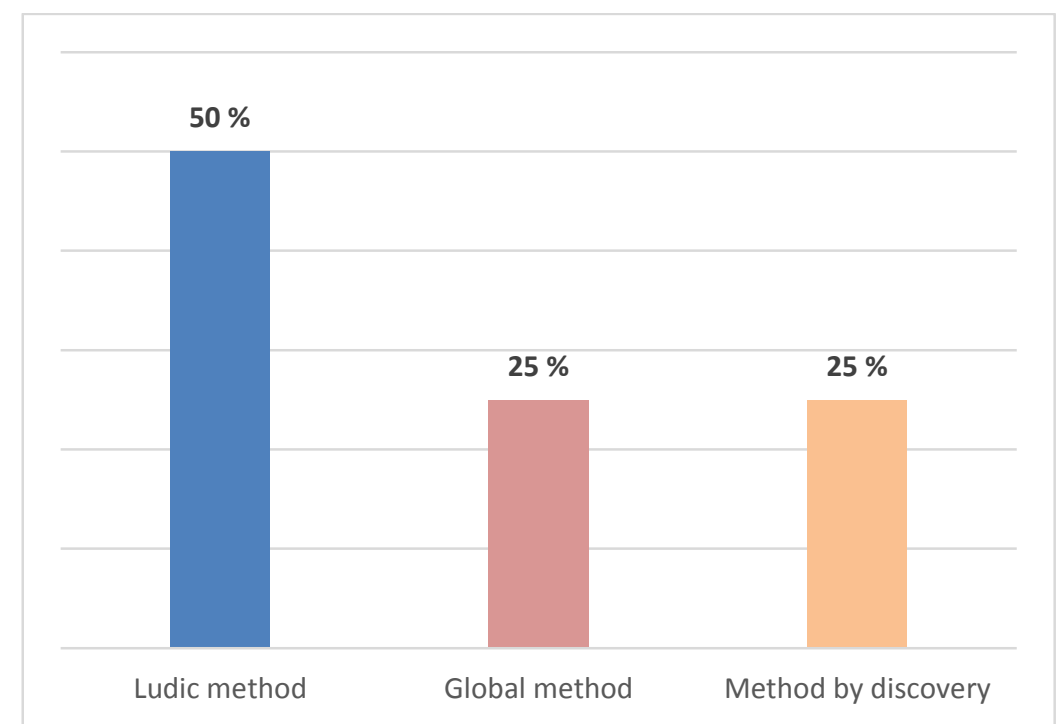

Figure 2. Teaching-learning methods applied in daily activities

Source: Survey of initial education teachers of the Diana Esther Guerrero Vargas Educational Unit

Álava, J. B. C., Vera, L. E. A., Tipán, V. F., \& Pinargote, G. V. L. (2021). Teaching-learning methods and their influence on the development of multiple intelligences of initial education. International Research Journal of Management, IT and Social Sciences, 8(6), 701-711. https://doi.org/10.21744/irjmis.v8n6.1970 
$50 \%$ are applying the playful method to develop multiple intelligences in children; $25 \%$ state that they use the global method while the other $25 \%$ of teachers use the discovery method (Benítez, 2010). In this way, it can be observed that teachers are applying active methodologies which favor the development of multiple intelligences. Play, therefore, has always been a teaching method to train the little ones in skills they needed to later face the tasks of everyday life. Applied to the educational institution, it does not turn out to be a novelty either since, in the Renaissance, importance was given to recreational activities that professionally prepared students. In figure 3 , it is possible to observe the activities that multiple intelligences develop in the teaching-learning process.

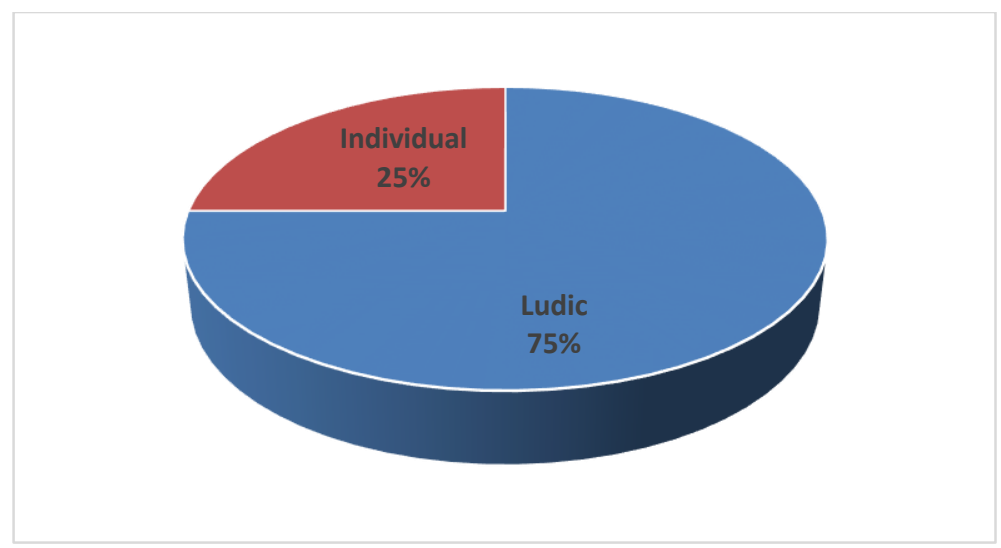

Figure 3. Activities during the teaching-learning process

Source: Survey of initial education teachers at the Diana Esther Guerrero Vargas Educational Unit

It is observed that $75 \%$ of initial education teachers surveyed from the Diana Esther Guerrero Vargas Educational Unit consider that recreational activities benefit the development of multiple intelligences and children's learning, which reveals that initial education teachers are developing playful activities during the teaching-learning process, while $25 \%$ considered that individual activities were better to apply when working in classes. as stated by (Martínez Yacelga \& Salinas Flores, 2020). Del-Moral-Pérez et al. (2014), argue that playful scenarios contribute to the development of multiple intelligences in school-age children. In figure 4, the activities that take place in initial education classes are observed.

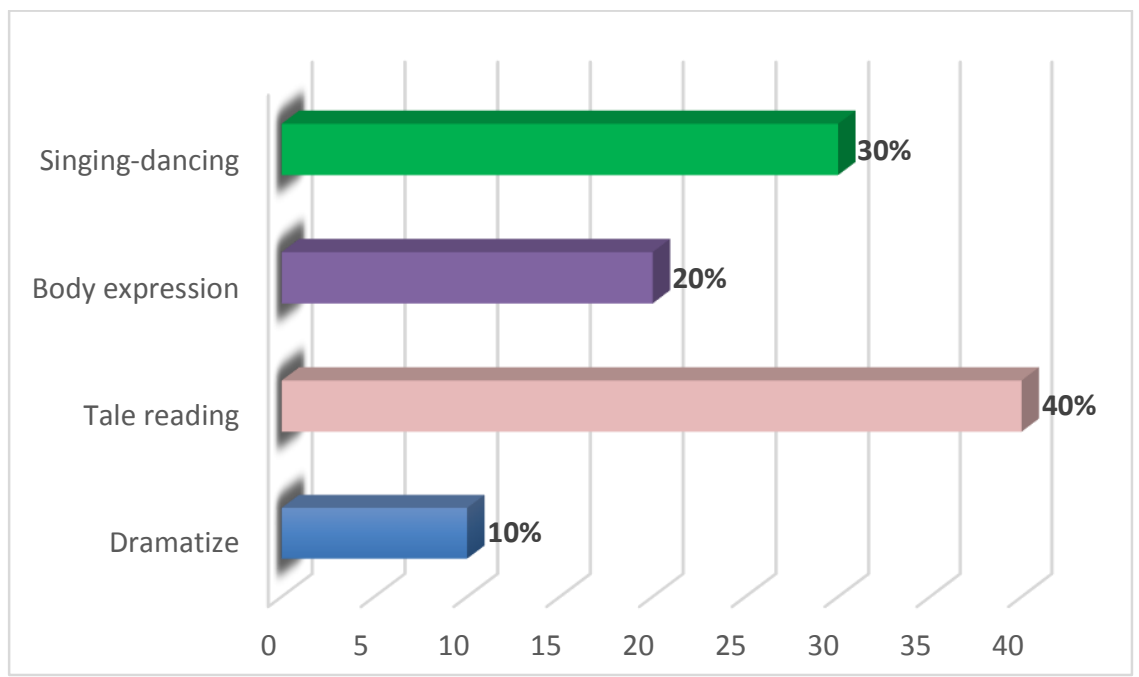

Figure 4. Classroom activities to develop multiple intelligence in early childhood education Source: Survey of initial education teachers of the Diana Esther Guerrero Vargas Educational Unit

It was obtained that $40 \%$ read stories as an activity to develop knowledge, 30\% express that they use singing-dancing to improve skills in their students, $20 \%$ body expression as an activity within classes, and $10 \%$ use role-play. This 
indicates that early childhood teachers carry out activities such as: singing, reading stories, dancing, dramatization as an activity to develop children's IQ. According to (Larragaña, 2012), it indicates that intelligence has been thought of as a unitary capacity and our current educational system still does not value equally the capacities that a student may have. This means that many do not discover their talent since the school continues to prioritize some abilities more than others. In figure 5, the teaching methods that are applied within the classrooms do influence the development of multiple intelligences in the initial stage of children.

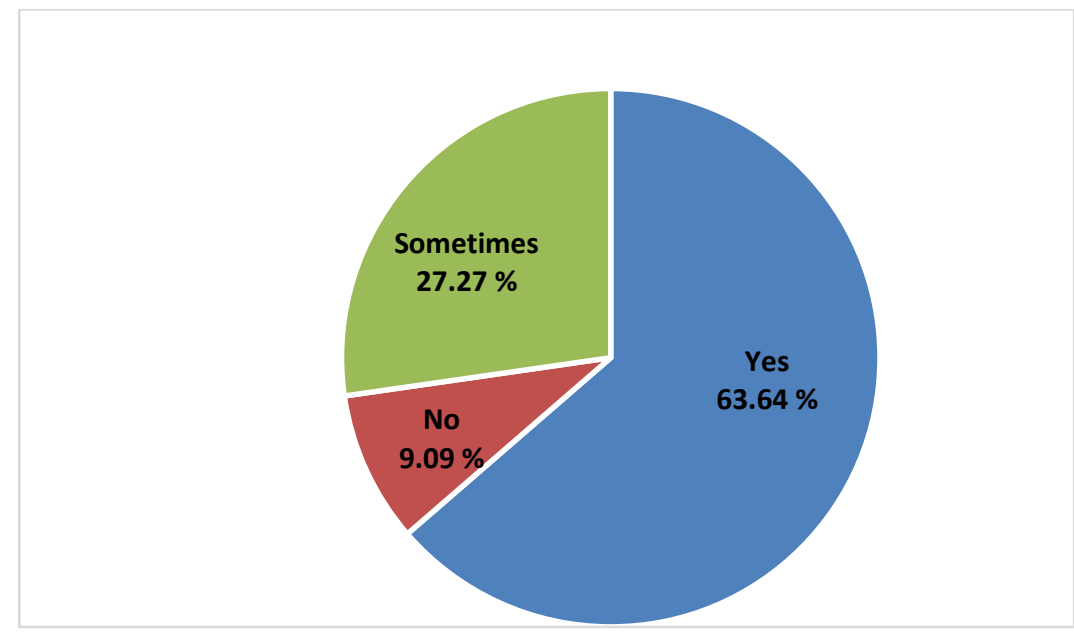

Figure 5. Teaching methods in the development of multiple intelligences

Source: Survey of initial education teachers of the Diana Esther Guerrero Vargas Educational Unit

As shown, $63.64 \%$ of the teachers surveyed consider that the teaching methods they use during the teaching-learning process influence the development of multiple intelligences, while $27.27 \%$ state that sometimes and $909 \%$ consider that it does not influence since other aspects such as the student's environment, emotional development or some type of educational need associated with the individual's cognitive development must be considered. As can be seen in Figure 6, the intelligence that is formed in initial education students within the classroom are varied, it depends on how the teacher guides and motivates the cognition process (Abenti, 2020; Lorenzo \& Lorenzo, 2013).

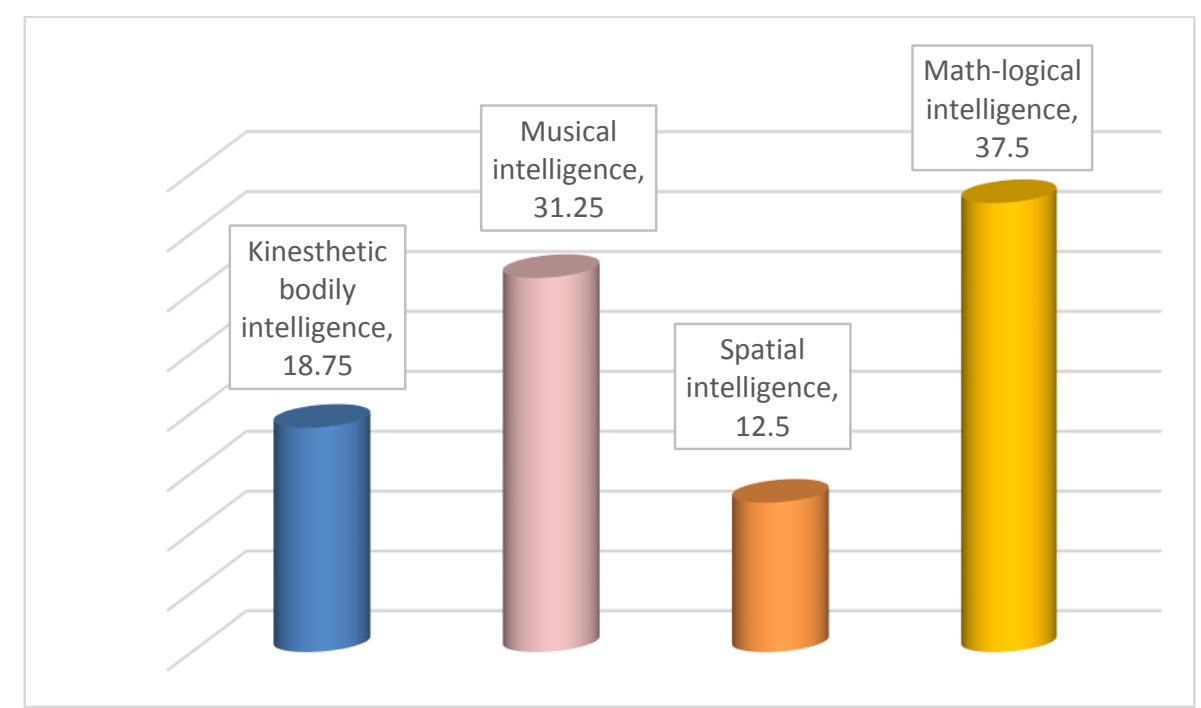

Figure 6. Intelligences developed in students

Source: Survey of initial education teachers of the Diana Esther Guerrero Vargas Educational Unit

Álava, J. B. C., Vera, L. E. A., Tipán, V. F., \& Pinargote, G. V. L. (2021). Teaching-learning methods and their influence on the development of multiple intelligences of initial education. International Research Journal of Management, IT and Social Sciences, 8(6), 701-711. https://doi.org/10.21744/irjmis.v8n6.1970 
The teachers surveyed have observed that their students have developed different types of intelligence, $37.5 \%$ express that logic-mathematics is present in most of their students, $31.25 \%$ express that musical intelligence, $18.75 \%$ argue that students develop body intelligence and $12.5 \%$ say that it develops spatial intelligence. To complement, he emphasizes the importance of including children's stories in the classroom, where environments are created for dialogue, questions, doubts, and, above all, universes according to the needs and interests of children. The story, seen from different perspectives, develops all thinking skills and social skills (Jiménez Ortíz \& Gordo Contreras, 2014). As shown in Figure 6, the traditional method can be applied in modern education to develop the cognitive process of children in early childhood education.

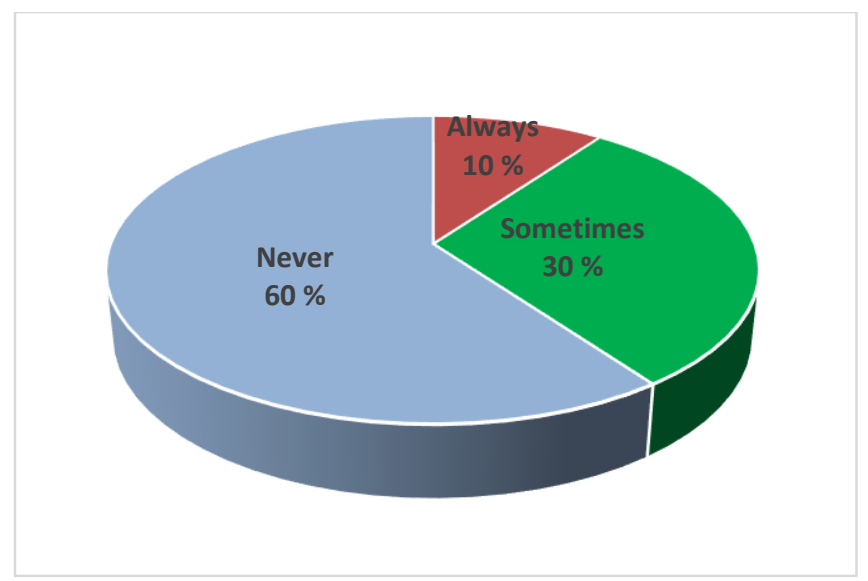

Figure 7. The traditional method in current education

Source: Survey of early childhood education teachers from the Diana Esther Guerrero Vargas Educational Unit

$60 \%$ of the teachers surveyed consider that the traditional method should not currently be applied, as there are new methodologies where students must be the protagonists when acquiring knowledge through different techniques, while $30 \%$ indicate that they almost always use this type of procedure since by combining them with new tools the student obtains significant learning, and only $10 \%$ stated that at present they do not use this practice considered ambiguous and that it does not contribute significantly in student development. According to (Larragaña, 2012), traditional education understands education as an accumulation of knowledge. But what they are looking for today are creative people, capable of adapting to new flexible situations, who know how to cooperate as a team, with self-confidence and this traditional education does not provide us with.

Multiple intelligences help to strengthen the concept of learning methods and how the method of Howard Gardner influences the development of positive intelligence in pre-school children. The important methodology of Gardner is to understand that no intelligence is more important than that and that all children, adolescents, and adults can always learn and when there is a correct motivation and application within the classrooms. In the study, it was verified that the teacher must also be creative at the time of teaching his class, to apply the playful corners within classes is that the students develop the different bits of intelligence that all human beings must achieve meaningful learning (Buchanan, 2012; González-Treviño et al., 2020).

The problem lies in the teaching methods that are applied, at the time of developing this intelligence in students, there are already teachers who apply traditional methodologies and who continue with the scheme that the teacher is the protagonist of learning when the opposite is true; It is he educating who creates his learning from his need and interest, the teacher should only be a moderator or guide, in addition, we must consider that we have to educate in diversity from equality (Akbari \& Hosseini, 2008; Shearer \& Karanian, 2017).

\section{Conclusion}

It was shown that multiple intelligences positively influence the teaching process of initial education where teachers must propose challenges and obstacles to students in different subjects, with the aim that the student develops new ways of understanding and learning using the appropriate methodological strategies such as play corners. The teacher must assess the abilities and attitudes of each child, relate them to the different curricular or learning areas. The 
Ecuadorian educational system within the curriculum by incorporating cultural and artistic education and physical education gives more interdisciplinarity to education

Conflict of interest statement

The authors declared that's they have no competing interests.

Statement of authorship

The authors have a responsibility for the conception and design of the study. The authors have approved the final article.

Acknowledgments

We are grateful to two anonymous reviewers for their valuable comments on the earlier version of this paper.

Álava, J. B. C., Vera, L. E. A., Tipán, V. F., \& Pinargote, G. V. L. (2021). Teaching-learning methods and their influence on the development of multiple intelligences of initial education. International Research Journal of Management, IT and Social Sciences, 8(6), 701-711. https://doi.org/10.21744/irjmis.v8n6.1970 


\section{References}

Abenti, H. F. (2020). How do I teach you? An examination of multiple intelligences and the impact on communication in the classroom. Language \& Communication, 73, 29-33. https://doi.org/10.1016/j.langcom.2020.04.001

Akbari, R., \& Hosseini, K. (2008). Multiple intelligences and language learning strategies: Investigating possible relations. System, 36(2), 141-155. https://doi.org/10.1016/j.system.2007.09.008

Alcivar, C. M. M., Quimi, T. L. I., \& Barberan, M. F. Z. (2020). The motivation and its importance in the teachinglearning process. International Research Journal of Management, IT and Social Sciences, 7(1), 138-144. https://doi.org/10.21744/irjmis.v7n1.832

Ardila, R. (2011). Intelligence. What do we know and what do we need to investigate? Journal of the Colombian Academy of Exact, Physical and Natural Sciences , 35 (134), 97-103.

Barrantes Montes, P. (2017). The playful method and its influence on the development of cognitive abilities in the area of Science, Technology and Environment in third year high school students of the Fe y Alegría Educational Institution $\mathrm{N}^{\circ}$ 25-UGEL 05 .

Benítez, GS (2010). Learning strategies through the playful component. marcoELE. Journal of Spanish Foreign Language Didactics , (11), 1-68.

Bezanilla, M. J., Fernández-Nogueira, D., Poblete, M., \& Galindo-Domínguez, H. (2019). Methodologies for teachinglearning critical thinking in higher education: The teacher's view. Thinking skills and creativity, 33, 100584. https://doi.org/10.1016/j.tsc.2019.100584

Buchanan, J. L. (2012). Prevention of depression in the college student population: a review of the literature. Archives of psychiatric nursing, 26(1), 21-42. https://doi.org/10.1016/j.apnu.2011.03.003

Cabezas Gómez, D. (2017). Intrapersonal intelligence and development in people with Down syndrome.

Chamorro, IL (2010). The game in early childhood and primary education. Self-taught, 1 (3), 19-37.

Cunska, A., \& Savicka, I. (2012). Use of ICT teaching-learning methods make school math blossom. Procedia-Social and Behavioral Sciences, 69, 1481-1488. https://doi.org/10.1016/j.sbspro.2012.12.089

Del-Moral-Pérez, ME, Guzmán-Duque, AP, \& Fernández, LC (2014). Serious Games: playful scenarios for the development of multiple intelligences in primary school children. Edutec. Electronic Journal of Educational Technology, (47), a267-a267.

Figueroa, YGM, Moreno, JAV, \& Gámez, MR (2021). A school with multiple intelligences: vision towards an innovative proposal. Cuban Journal of Higher Education , 40 (1).

González-Treviño, I. M., Núñez-Rocha, G. M., Valencia-Hernández, J. M., \& Arrona-Palacios, A. (2020). Assessment of multiple intelligences in elementary school students in Mexico: An exploratory study. Heliyon, 6(4), e03777. https://doi.org/10.1016/j.heliyon.2020.e03777

Heredero, ES, \& Ceballos, MDPG (2017). Development Of Interpersonal And Intrapersonal Intelligence In Primary Education Based On The Use Of Information And Communication Technologies. Notandum , (44-45), 175-188.

Jiménez Ortíz, ML, \& Gordo Contreras, A. (2014). The children's story: facilitator of thought from a pedagogical experience. Praxis \& Saber, 5 (10), 151-170.

Larrañaga, A. (2012). The traditional educational model versus new learning strategies (Master's thesis).

Lorenzo, A. R., \& Lorenzo, B. U. (2013). Learning styles of teacher education students: Basis in improving the teaching-learning process. Procedia-Social and Behavioral Sciences, 103, 595-605. https://doi.org/10.1016/j.sbspro.2013.10.377

Martínez Yacelga, ADR, \& Salinas Flores, PP (2020). The educational game for the strengthening of multiple intelligences. Uniandes EPISTEME , 7 (3), 422-436.

Ruiz, E. (2016). A whole world of emotions. Emotional education and well-being in Down syndrome. Madrid. CEPE .

Saquinga Alcaciega, MV (2016). The learning by discovery in the creativity of the students of the seventh year of basic education of the "Ernesto Bucheli" school of the Ambato canton, Tungurahua province (Bachelor's thesis, Technical University of Ambato. Faculty of Human Sciences and Education. Education career Basic).

Shearer, C. B., \& Karanian, J. M. (2017). The neuroscience of intelligence: Empirical support for the theory of multiple intelligences?. Trends in neuroscience and education, 6, 211-223. https://doi.org/10.1016/j.tine.2017.02.002

Sulaiman, T., Abdurahman, A. R., \& Rahim, S. S. A. (2010). Teaching strategies based on multiple intelligences theory among science and mathematics secondary school teachers. Procedia-Social and Behavioral Sciences, 8, $512-518$. https://doi.org/10.1016/j.sbspro.2010.12.070

Torres-Silva, L., \& Díaz-Ferrer, J. (2021). Multiple intelligences in strengthening effective cooperative learning. IPSA Scientia, multidisciplinary scientific journal , 6 (1), 64-80. 
Zambrano, Ángela V. H., Cantos, U. del C. C., \& Chilan, Y. G. T. (2021). Methodological strategies for the development of multiple intelligences in tenth year students. International Research Journal of Management, IT and Social Sciences, 8(6), 690-700. https://doi.org/10.21744/irjmis.v8n6.1971

Zou, F., Wang, L., Hei, X., \& Chen, D. (2015). Teaching-learning-based optimization with learning experience of other learners and its application. Applied Soft Computing, 37, 725-736. https://doi.org/10.1016/j.asoc.2015.08.047

Álava, J. B. C., Vera, L. E. A., Tipán, V. F., \& Pinargote, G. V. L. (2021). Teaching-learning methods and their influence on the development of multiple intelligences of initial education. International Research Journal of Management, IT and Social Sciences, 8(6), 701-711. https://doi.org/10.21744/irjmis.v8n6.1970 